\title{
Transatlantica
}

Revue d'études américaines. American Studies Journal

$2 \mid 2011$

Sport et société / Animals and the American

Imagination

\section{Racial Fault-lines in "Baseball's Great Experiment:" Black Perceptions, White Reactions}

Henry D. Fetter

\section{(2) OpenEdition}

Journals

Electronic version

URL: https://journals.openedition.org/transatlantica/5462

DOI: $10.4000 /$ transatlantica.5462

ISSN: 1765-2766

Publisher

Association française d'Etudes Américaines (AFEA)

Electronic reference

Henry D. Fetter, "Racial Fault-lines in "Baseball's Great Experiment:" Black Perceptions, White

Reactions", Transatlantica [Online], 2 | 2011, Online since 19 June 2012, connection on 01 February

2023. URL: http://journals.openedition.org/transatlantica/5462 ; DOl: https://doi.org/10.4000/

transatlantica.5462

This text was automatically generated on 1 February 2023.

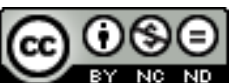

Creative Commons - Attribution-NonCommercial-NoDerivatives 4.0 International - CC BY-NC-ND 4.0 https://creativecommons.org/licenses/by-nc-nd/4.0/ 


\title{
Racial Fault-lines in "Baseball's Great Experiment:" Black Perceptions, White Reactions
}

\author{
Henry D. Fetter
}

\section{Introduction}

1 Over sixty years after his first appearance in a Brooklyn Dodger uniform in the spring of 1947, the broader social significance of Jackie Robinson's breaking major league baseball's color line remains subject to debate. "The saga of Robinson's first season has become a part of American mythology," the late Jules Tygiel wrote in his classic account of the integration of baseball, "sacrosanct in its memory, magnificent in its retelling. [...] It is a tale of courage, heroics, and triumph. Epic in its proportions, the Robinson legend has persevered [...] because the myth, which rarely deviates from reality, fits our national perceptions of fair play and social progress" (Tygiel, 1983, 206). "The events unleashed by the historic alliance between Robinson and Rickey significantly altered American society," and even "if the vision of an integrated and equal society, free from racism and discrimination, which impelled Rickey and Robinson to launch their 'great experiment,' remains unfulfilled," Tygiel concluded, "their efforts have brought it closer to reality" (Tygiel, 1983, 343-44).

Robinson himself later recalled that "integration in baseball has already proved that all Americans can live together in peaceful competition" (Robinson, 1964, 11). Monte Irvin, the first black ball player signed by Brooklyn's arch rivals, the New York Giants, similarly claimed that "baseball has done more to move America in the right direction than all the professional patriots with their billions of cheap words" (quoted in Robinson, 1964, 96). When Robinson died in 1972, veteran New York Times sports writer Leonard Koppett summed up his legacy by writing, "the consequences of the waves his appearance made spread far beyond baseball, far beyond sports, far beyond politics, even to the very substance of a culture." (quoted in Tygiel, 1983, 344). 
3 This heroic narrative has, however, met with resistance from those who have questioned the actual impact of "baseball's great experiment" on American race relations in general. Fifty years after Robinson's 1947 breakthrough, historian Joram Warmund wrote that "baseball supposedly was one of the great definers and influencers of American values. Yet, it did not have the spillover effect one might have expected; certainly not in the immediate future [...] even if 'baseball' was progressive, its influence was either not that great or it was of a more subtle and long-range nature" (Warmund, 1998, 8-9). In his recent account of the struggle for civil rights in the north, Thomas Sugrue similarly expressed doubts about the broader significance of Robinson's example:

In 1947, when the Brooklyn Dodgers fielded Jackie Robinson, the event became a barometer of changing race relations and a reminder of how deeply entrenched racial hostility remained in the North. [...] By the time of his retirement in 1957, Robinson had become a celebrity whose personal life was fodder for the black press and whose compelling story of triumph over racial injustice turned him into the white media's feel-good example of America's changing racial order. But Robinson's breakthrough, however celebrated, was largely symbolic. It would take much more than a handful of black sports heroes to transform race relations in postwar America (Sugrue, 2008, 121).

4 This essay will not attempt to adjudicate between these differing perspectives, both of which might be said to suffer from the "hindsight bias" inherent in evaluating the significance of a past event in the unavoidable light cast by knowing what happened. Instead, it will examine three facets of "baseball's great experiment" based on the contemporaneous record-the perception of blacks, the response of white players (whether teammates or opponents), and the reaction of baseball fans. The goal is to portray the context within which baseball's color line was broken and to illuminate the fault-lines that characterized race relations within both the sport of baseball and the larger society as each was confronted with new challenges to long established policies and practices in the years after the Second World War.

\section{Black Perceptions, White Motives}

5 Wendell Smith, sports columnist for the Pittsburgh Courier, a widely circulated AfricanAmerican newspaper, was perhaps the most prominent black sports writer in the 1940s. Long a crusader for the integration of major league baseball, Smith was hired by Brooklyn Dodger team president and general manager Branch Rickey to act as Jackie Robinson's spokesman and roommate during Robinson's first season with the Dodgers. In that capacity, Smith was the ghost writer of Robinson's weekly record of his rookie season under the title "Jackie Robinson Says" for theCourier, and would later do the same forJackie Robinson: My Own Story, the autobiography published in the spring of 1948 (Wiggins, 1983, 5-29). However, one theme that Smith emphasized in his own writing was surely not what Rickey had in mind when he forged that protective and mutually advantageous relationship between rookie ball player and veteran reporter. It was one, however, that likely resonated with readers of theCourier who were not inclined to assume white benevolence when it came to dealing with blacks.

That theme, pounded out over and over again in Smith's coverage of Robinson's debut with the Dodgers, was that Rickey's motivation in signing Robinson was the resulting financial gain that would accrue to the Dodgers and Rickey. Smith repeatedly dwelled 
on the financial aspect of "baseball's great experiment." Most famously, Smith coined the still oft cited jingle "Jackie's nimble/Jackie's quick/ Jackie's making the turnstiles click." (Pittsburgh Courier [PC]31 May 1947). "Crowds like these," Smith wrote of the Dodgers' pre-season exhibition series against the Yankees, "represent money. Rickey knows that, and is now satisfied that he made a good business deal when he signed Jackie to a Brooklyn contract" (PC 19 April 1947). Smith continued:

Rickey is a shrewd businessman. He knew when he signed Jackie that he had cornered the greatest drawing card since Babe Ruth. Robinson will probably prove to be the best drawing card in baseball during the 1947 season. In the meantime Rickey is sitting in the office counting out the money (PC 19 April 1947).

7 As Smith accompanied the Dodgers around the National League circuit that spring, he toted up a total of 358,046 fans who had paid their way in to see the Dodgers in New York, Philadelphia, Cincinnati, Pittsburgh, Chicago and St. Louis. After the Dodgers attracted a record crowd of 46,572 to Chicago's Wrigley Field, Smith wrote "that amazing crowd merely proved to dubious owners that Branch Rickey grabbed a coppercolored gold mine when he signed Jackie Robinson" (PC 24 May 1947). Smith dubbed Robinson "Mr. Drawing Power." "This much is certain," Smith wrote, "the fans want to see Jackie," and "merely prove the shrewdness of Branch Rickey and how smart he was in signing up Robinson. If the Dodgers play good enough ball to stay in the race, Mr. Rickey will be carrying his money home in sacks (first base sacks, that is) come the September breezes" (PC 31 May 1947). According to Smith, Dodger statistician Allen Roth, who traveled with the team, was not there "to chart the playing prospects of the Dodgers." "Actually," Smith claimed, "the figure Filbert was concerned with was Robinson's draw at the gate. While Branch Rickey hopes eventually to see Jackie Robinson accepted as just another ballplayer, he is not overlooking the novelty value of his colored star at this time" (PC 14 June 1947).

8 In fact, some of what Smith wrote in pursuit of this theme exaggerated Robinson's drawing power. The 79,441 fans attending the Dodgers' three game pre-season exhibition series against the Yankees in April 1947, which featured Robinson's first appearances in Brooklyn livery, was not "about twice as many fans as the Yankees and Brooklyn attracted in annual spring exhibition before," as Smith claimed (PC19 April 1947), but just slightly more than the 73,438 who had attended the three game set in 1946. Nor was Smith correct when he cited the 30,847 fans at the Sunday finale of the 1947 series as "probably the biggest crowd to see an exhibition game in the history of the majors" (PC 19 April 1947); just one year earlier, on 14 April 1946, 33,187 fans had attended that day's Dodger-Yankee clash.

More generally, much of the ballyhoo then and later about Robinson's unmatched drawing power ignored the fact that Dodger home game attendance in 1947 was just slightly higher than in $1946(1,807,526$ compared to $1,796,824)$ and that, although Dodger road game attendance in Robinson's first season increased by $21 \%$ over the 1946 mark (1,863,000 in 1947, 1,534,000 in 1946), attendance in games at "enemy" ballparks not involving Brooklyn increased by a comparable 20.5\% (Fetter, 1998, 183-192). The rising tide of the post-war baseball boom was lifting all boats-if Branch Rickey was "sitting in the office counting out the money," so too were his less venturesome peers. In fact, Rickey did not need Robinson to be sitting atop the National League's most lucrative franchise. 
10 Nor did Smith do justice to the record when he suggested that Boston city councilman Isadore Muchnick was similarly motivated by self interest when he pressured the Red Sox into giving a group of black ballplayers, organized by Smith and including Jackie Robinson, a tryout in the spring of 1945. The Jewish Muchnick, Smith claimed, was seeking electoral advantage by seizing on the baseball integration issue in order to win favor in his largely black council district (Norwood and Brackman, 1999, 124-25). In fact, Muchnick's district was almost entirely white and Jewish at the time as historians Stephen Norwood and Harold Brackman demonstrated in an important article based on detailed examination of contemporary census data (Norwood and Brackman, 1999, 125). As journalist John Gunther wrote at the time, "there are [...] sixty thousand Jews packed in a single 'sociological enclave' in one Boston district, who form the most solidly Jewish community in the whole country" (Gunther, 1947, 516). Nevertheless, the narrowly political and self-interested-but erroneous-explanation for Muchnick's effort advanced by Smith has been endorsed by numerous writers, including Jackie Robinson himself (Norwood and Brackman, 1999, 124-25; Rowan, 1960, 97). Indeed, according to the most recent full-length account of the Jackie Robinson story, Smith claimed entirely undeserved credit for putting the idea of challenging the color line in Muchnick's head in the first place (Eig, 2008, 135).

11 By deprecating Muchnick's initiative in this fashion, Smith provided a striking example of the view, that would come to be held by influential figures in the black community, that Jewish involvement in the civil rights movement was motivated by self-interest, not common concerns, let alone idealism (Friedman, 1995, 7-9). More generally, that blacks might question, or be wary of, white motives in civil rights initiatives would become manifest with the rise of the black power movement in the 1960s, but it was a note that Smith was already sounding (to those who troubled to listen) even at a moment of triumph for the multi-racial partnership that Rickey and Robinson so publicly and so productively represented.

\section{Teammates and Opponents: Integration and Its Limits}

12 If white self-interest, in the form of Dodger president Branch Rickey's financial return on Robinson's breakthrough, provided an important theme for Smith's coverage of Robinson's rookie season, so too did Rickey and other baseball executives have to take into account the self-interest of the one group of whites most directly affected by the sport's integration-the existing all white cadre of professional ballplayers, whether already in the major leagues or in the minor leagues and aspiring to that status. Resentment and opposition from fellow ballplayers might, of course, have well been expected, and not for narrowly racist reasons alone. In 1947, the sixteen clubs in the Major Leagues stood at the thin apex of a massive pyramid of talent in organized baseball, all of it white. For every one of the 400 (white) men on major league rosters, there were 25 potential replacements on the almost 500 minor league teams then competing in five dozen leagues-a total of about 10,000 minor leaguers, white to the last man (U.S. Senate, 1953, 19).

13 An influx of talent from any new source posed a direct threat to the aspirations, not to mention the livelihood, of these thousands at a time when almost everyone in the professional baseball world entered it after high school graduation, at most, and the likely alternative to a career in baseball for many was the mine, the mill, the farm or 
the filling station. This was a ready-made formula for hostility. After all, during the recent war, the entry of blacks into jobs previously reserved for whites, had unleashed "hate" strikes and other protests from embittered and resentful white war workers, not only in Alabama shipyards or Baltimore defense plants, but in Detroit auto factories, and the Philadelphia transit system, conflicts which even the overriding exigencies of wartime had been unable to prevent (Polenberg, 1972, 120-21; Burns, 1970, 462, 510; Glazer and Hoffman, 1944, 306-8).

There was no reason to believe that the tightly knit, segregated world of organized baseball would be any different. Major leaguers were concerned about the competition they would face if their all white ranks were opened to blacks (Lowenfish, 2007, 381). As Negro League star Buck O'Neill would later observe, "for Jackie to play in the major leagues, that meant that one white boy wasn't going to play" (quoted in Ward and Burns, 1994, 230). Indeed, it would not be until July 1947, over a year and a half after Robinson had signed a contract with the Dodger organization, that another major league club followed Rickey's lead. Bill Veeck the liberal minded owner of the Cleveland Indians recalled that, when he met with Cleveland ball players after engaging Larry Doby as the team's (and American League's) first black player, "there were a couple of grumbles [...]. I think it represented an economic threat to them" (quoted in Tygiel, 1983, 215).

At the time he signed Doby, Veeck explained that "Robinson has proved to be a real big leaguer, so I wanted to get the best available Negro boy while the getting was good. "Why wait?" (New York Times, 4 July 1947). "The entrance of Negroes into the majors is not only inevitable-it is here," Veeck said, which the press understood him to mean that "a wide-open scramble for Negro players now was under way" (New York Times, 4 July 1947). Rickey, for his part, was said to anticipate that within a year or so the color line would be eradicated completely from baseball ("Veeck Predicts," 16 July 1947)1. Within two weeks, however, Veeck was beating a hasty retreat, telling reporters that

fewer than six players worthy of consideration remain in the Negro leagues [...] [A]s the years go by, we'll have an increasing number of colored boys in the majors. But now, there is no chance of a large-scale influx [...]. At present there is no possibility that Negro players will be arriving in wholesale numbers in the majors ("Best Negro Players Already Taken," 30 July 1947).

Surprisingly, Branch Rickey was reported to concur with Veeck's assessment of the lack of big league talent among the current crop of black ball players and that "I don't believe that too many [black ball players] will make good, not enough for distribution around the National and American leagues. (Tygiel, 1983, 225; "Veeck Predicts," 16 July $1947)^{2}$.

17 Jules Tygiel has written that "the rationale for these proclamations remains unclear" since "both the Dodgers and Indians had scouting reports that indicated otherwise" (Tygiel, 1983, 225). One possible explanation, consistent with Rickey's cautiously elaborate, perhaps even overly so, preparations for Robinson's break through (see Tygiel, 1983, 161-63; Mann, 1963, 160-65), is that Rickey had read with interest Gunnar Myrdal's monumental study of An American Dilemma: The Negro Problem and American Democracywhen it was published in 1944 (Lowenfish, 2007, 351). Myrdal's formula for the successful integration of the work force, consciously or not, was replicated by Rickey, and organized baseball generally, when it came to introducing blacks into the major leagues. "If Negro workers are introduced a few at a time," Myrdal wrote, "if they are carefully picked, if the leaders of the white workers are taken into confidence, 
and if the reasons for the action are explained, then the trouble can be minimized, and the new policy may eventually become successful" (Myrdal, 1962, 389; Jennings, 2007).

In a preview of the Supreme Court's "all deliberate speed" 1955 mandate for implementing its public school integration decision inBrown v. Board of Education, gradualism prevailed when it came to the entry of black ball players into major league baseball (Lowenfish, 2008, 52-61). Robinson's and Doby's debuts in 1947 did not signal an all out assault on the segregationist patterns that remained entrenched in much of the baseball world. Five years later, only six of the sixteen major league clubs had blacks on their rosters. It would not be until 1957 in the National League and 1959 in the American League that the last holdouts to integrating their rosters (the St. Louis Cardinals and the Boston Red Sox, respectively) would give way. Nor did the breaking of the color line transform traditional perspective on issues of race. The Sporting News, baseball's weekly paper of record, had been gracious enough to transcend its previous segregationist rhetoric and honor Jackie Robinson as its first Rookie of the Year in 1947, but an insensitive mindset persisted among its staff that could produce the caption "Toiling on the Tribe Plantation" for an April 1949Sporting Newsphotograph of several blacks in the Cleveland farm system ("Toiling on the Tribe Plantation," 13 April 1949)3.

Viewed in retrospect, what is especially striking is that the slow and limited pace of integration did not prevent those who had supported Robinson's challenge to the color bar from passing favorable judgment on the state of the sport's race relations at the time. In a survey of the state of the sport's race relations that was published in 1954, Dan Dodson, a white New York University sociology professor and civil rights activist who had been an advisor to Rickey, observed that there were 22 blacks then playing in the Major Leagues (out of about 400 regular players) and that one half of the 16 teams in the big leagues, remained all white. What might well have appeared as strong evidence of the persistence of the sport's segregationist traditions did not deter Dodson from declaring victory in the fight against racism in baseball. Writing that such continued racial exclusion involved "only eight clubs," [emphasis added] Dodson's upbeat conclusion was that "in eight years America's most prominent national sport has moved from a tradition of seventy years discrimination to almost complete integration" [emphasis added] (Dodson, 1954, 73).

Yet however slowly the number of blacks in the major leagues increased after 1947, overt racial tensions would flare up from time to time, sometimes in surprising places. Eddie Stanky, a supportive teammate to Robinson in his difficult rookie season, would orchestrate a barrage of racially tinged bench jockeying as the manager of the Cardinals five years later (Prince, 1996, 11-12; Tygiel, 1983, 308). Even more notably, and contrary to the public depiction of the team as a color blind band of brothers, the integration of the Dodgers triggered racial tension in the clubhouse that came to a head when Robinson replaced veteran Billy Cox at third base to make room for rookie Gilliam at second in 1953 (Prince, 1996, 11-15; Tygiel, 1983, 307-8; Rampersad, 1997, 173). It may well have been that it was precisely the slow pace of integration that mitigated an adverse reaction from white major leaguers in the years after Jackie Robinson's breakthrough. 


\section{In the Grandstand and Beyond: What Price Integration?}

21 It has become a commonplace to salute the setting for the breaking of baseball's color line and say that "if Jackie Robinson was the ideal man to break the color barrier, Brooklyn was the ideal place" (Veeck, 1976, 178). According to the editors of an important symposium on Robinson and "race, sports and the American dream," "a mélange of ethnicities, a pastiche of cultures, [Brooklyn] [...] proved a hospitable laboratory for the 'great experiment'. It can be said forcefully -indeed proclaimed proudly-that Brooklyn was central in challenging our nation's pervasive racism" (Dorinson and Warmund, 1998, xxi). "Why was it that when Jackie came up to the Dodgers in 1947, he was beloved in Brooklyn but hated just about every place else?" oral historian Peter Golenbock recently asked (Golenbock, 2008, 665).

However, the reality was more complicated, as indeed Golenbock himself had previously recognized. "There were blue collar adults," Peter Golenbock recorded in his oral history of the Dodgers first published in 1984, "who loathed what Robinson's presence symbolized: rivalry from the Negro worker". As one of his interviewees then recalled,

when Jackie Robinson came up there were a lot of adults who dropped their allegiance to the Dodgers. There was a lot of bigotry, among the working class more than anything: the Irish, the Italians, the Swedes. They said, 'I'm never gonna root for them again, Goddamn it.' It was a lot of union guys saying, 'Sure, first they get into baseball, and then they'll be taking my job' (Golenbock, 2000, 148).

Social historian Carl E. Prince has described heightened racial tensions between Brooklyn's entrenched white ethnic groups and the increasing numbers of newly arriving blacks in the years after World War II. "Despite the presence of black ballplayers," the Dodgers "did not build a bridge to African-Americans in Brooklyn," Prince writes, concluding that "an increasing black presence in the population sent out shock waves, a reaction seemingly divorced from the example of Brooklyn's almost uniquely integrated ball club" (Prince, 1996, 113-15). Some fans, particularly those of a progressive political bent such as future civil liberties lawyer Ira Glasser may have celebrated the fact that "in 1947 Ebbets Field was the only integrated public accommodation in America" (Golenbock, 2008, 165). Historian of "Working Class New York" Joshua Freeman has, however, observed that "integration brought tension to the stands at Ebbets Field, which were no longer homogeneously filled by working-class white men" (Freeman, 2000, 34). The extent to which "the Dodger faithful, perhaps begrudgingly, accepted or were even proud of the team's role in breaking down racial exclusion," as Freeman also contends, may be doubted (Freeman, 2000, 34).

The increased black presence in the Ebbets Field grandstand reflected the changing racial composition of the Dodgers' home borough-but with a significant difference. During the 1940s, the black population of Brooklyn had increased from 107,263 to 208,478 (Rosenwaike, 1972, 133). The increase did not mark a breakdown in existing patterns of residential racial segregation. Almost two thirds of the black population was concentrated in the Bedford-Stuyvesant neighborhood in north central Brooklyn (whose proximity to Ebbets Field spurred black attendance at the nearby ballpark, but would become of increasing concern to Dodger management as it considered the future of the team in Brooklyn over the ensuing decade) whose black population more than 
doubled in the 1940s from 65,166 to 137,436 (Freeman, 2000, 183). "It was during this decade that Bedford-Stuyvesant as a large, impacted, overwhelmingly black ghetto was formed" (Freeman, 2000, 183; Connolly, 1977, 130). Meanwhile, vast swatches of the borough remained almost entirely white, and Brooklyn's "segregation index" actually increased during the 1940s, indicating "the pervasive character of racial segregation" (Connolly, 1977, 142 n. 4; Wilder, 2000, 202-4)4. Jackie Robinson himself had trouble finding suitable housing when he first joined the Dodgers, and when he did move, along with his wife and young son, into a largely white neighborhood, the new local hero faced opposition from a number of their new neighbors (Rampersad, 1997, 195-96).

Accompanying the upward spike in black population between 1940 and 1950, and "equally portentous for Brooklyn's demographic future, was a modest 50,000 decline in the number of its white residents, the first such decrease since the eighteenth century" (Connolly, 1977, 129), as a number of white neighborhoods experienced net population losses (Wilder, 2000, 194-95). That out-migration would become a flood in the 1950s as almost half a million whites headed to the suburbs in that decade while the black population increased to 371,405 (Rosenwaike, 1972, 133, 136-37). In the critical assessment of Craig Steven Wilder, "the integration of its famous baseball team was a mild accomplishment when measured against Brooklyn's extraordinary social divisions" (Wilder, 2000, 209). Wilder has even argued that "by attacking Jim Crow in professional sports, local officials were able to grandstand as champions of racial equality without tackling the politically costly issues of employment and housing discrimination" (Wilder, 2000, 208).

Within a demographic setting undergoing rapid change, Ebbets Field provided a decidedly unfamiliar breach in a social order that remained largely segregated and provided a racially mixed ambiance that may well have been uncomfortable to many of the team's traditional fans. Beginning with Wendell Smith, the contention has been repeatedly made that Brooklyn's breaking of the major league baseball color line paid dividends at the box office. Indeed, Smith's bottom line oriented assessment of Rickey's motives would be shared by Walter O'Malley, Rickey's successor at the Dodgers' helm, who told Roger Kahn, chronicler of Brooklyn's legendary "boys of summer," that "Rickey's Brooklyn contract called for salary plus a percentage of the take, and during World War II the take fell off. It was then Rickey mentioned signing a Negro. He had a fiscal interest" (Kahn, 1972, 426). A similar perspective has also been advanced by prominent legal scholar Michael Klarman. In a revisionist assessment that downplays the role of the courts in the dismantling of segregation, Klarman has written that

black economic clout also played an important role in the desegregation of the national pastime. [...] the addition of Jackie Robinson to Branch Rickey's Brooklyn Dodgers in 1947 produced throngs of black fans at Dodgers' games [...] as blacks throughout the nation flocked to watch Robinson represent his race (Klarman, 1994, 58).

This is a widely repeated claim but major league attendance figures do not establish that racial integration on the playing field translated into a box office bonanza in the grandstand for the Dodgers-or for the other teams that integrated most quickly thereafter. Ebbets Field was only about one third full on April 10, 1947 when Robinson made his first appearance in Brooklyn, playing for the Montreal Royals (the team he had played for in 1946), the Dodgers' top minor league affiliate, in a Royals-Dodgers exhibition game, sharply down from the 25,000 attracted the year before to his local debut at Jersey City in a Royals-Jersey City minor league game. When the Dodgers 
opened the 1947 season at Ebbets Field on April 15, with Robinson in the starting lineup, the turnout of 26,623 was the smallest at any NL ballpark that day, and 5000 lower than at the Dodgers' Ebbets Field season opener the year before. For Robinson's second Ebbets Field game that spring, attendance dropped to 10,252, about 3,500 fewer fans than attended a minor league game that day across the Hudson in Newark, New Jersey. In fact, rather than seeing record setting crowds thronging to Brooklyn's ballpark, after fifty home games in 1947, Dodger Ebbets Field attendance was lower than it had been in 1946 (Fetter, 1998, 186).

Robinson's appearance in Dodger flannels did, however, undoubtedly inspire unprecedented numbers of blacks to venture into Ebbets Field for the first time. Although the oft-cited claim that 14,000 blacks attended the Dodgers' home opener (see Tygiel, 1983, 178; Golenbock, 2008, 159) lacks any reliable contemporaneous source ${ }^{5}$, newspapers did report that "thousands" of black fans had been thronging Ebbets Field to see Robinson in action in the Dodgers' final pre-season games (New York Times12 April 1947; PM 11 April 1947). Lester Rodney, sports editor of the CommunistDaily Workerlater observed that "there were clearly more African-Americans in attendance [at the Dodgers' 1947 season opening game] than, say, at Opening Day the year before, though hardly the overwhelming increase that some had expected and some had feared" (Rodney, 61). Wendell Smith estimated that a total of 25,000 blacks attended the Dodgers' first four games in 1947, two of which were played at Ebbets Field and two at the Giants' Polo Grounds home, with 10,000-15,000 in the Saturday game at the Polo Grounds and the "remaining number turned out for the other three tilts" (PC 26 April 1947). If evenly divided among those other games, that would make for about 4,000 per game. A veteran white reporter calculated that the percentage of blacks in the crowd increased from about $2 \frac{1}{2}$ percent before Robinson's arrival to 10 percent afterwards (Roeder, 1950, 144). That percentage apparently increased as the years passed and Rodney recalled that by 1949 about one third of the crowd at a sold out game he attended that summer was black (Rodney, 1998, 89).

By the end of Robinson's debut 1947 season, Dodger attendance had inched above that for the prior season, $1,807,000$ compared to $1,796,000$. Given the virtually equivalent attendance figures in both seasons, and the generally acknowledged significant increase in black patronage, the number of white fans at Ebbets Field must have dropped substantially in Robinson's debut season. Reports that outfielder Fred "Dixie" Walker, theretofore the Dodgers' most popular player known as the "the People's Choice," but (as his nickname suggests) a white Southerner who was unwilling to play alongside Robinson, was now being booed "lustily and even profanely" (White, 26 April 1947) at Ebbets Field antagonized some white fans, one of whom claimed that the boos "came from 'Communists, extreme left wing and bleeding heart groups,'" (quoted in Daily Worker26 April 1947) and indicated that the comfortably familiar atmosphere at the ballpark was undergoing a change that would be upsetting to many of the team's faithful followers (Rampersad, 1997, 170;PC 19 April, 26 April 1947; New York Times11 April 1947;PM 11 April 1947). Some integration supporters may have applauded the boos directed at Walker as a well-deserved slap at racism (Chicago Defender26 April 1947) but for many other Dodger fans they signaled that an unsettling change was at hand, and that Dodgerdom would be subject to the same stresses and internal divisions that were roiling the larger society. 
30 Newspaper reports of "thousands" of black fans thronging Ebbets Field may well have discouraged a number of white fans to avoid the racial integration that now marked the grandstand as well as the playing field (New York Times12 April 1947;PM 11 April 1947; Eig, 2008, 52-53). One fan even wrote Robinson himself, complaining that the "conduct of 'SOME' of your race in the stands (drinking and boisterousness) could be improved upon," warning that such conduct (along with the booing of Walker) "will sooner or later hurt your race to gain an equal footing in their fight for equality" (quoted in PC26 April 1947). Civil rights leader and chairman of the National Association of Colored People (NAACP) Walter White felt compelled "to plead with that minority of Negroes who appear to believe a baseball game can be seen only through a haze of alcohol to postpone their drinking until after the games in which they go to see Jackie" and to curb the "loud-mouthed profanity, vulgarity and fighting" that had led him to eschew attending Negro League games in recent years (White, 26 April 1947).

Although at least a certain amount of the initial wariness of white fans about being part of a crowd that included large numbers of blacks for the first time wore off after a few months (Eig 161), white fans never again attended Dodger home games in their preRobinson numbers. Computation of "attendance strength" for major league clubs (a measure of the "expected share of league attendance for the average major league club of the same playing ability") calculated as part of the congressional anti-trust inquiry into organized baseball in 1951, showed attendance for the Dodgers in the late 1940s dropping below historical attendance levels for teams compiling comparable won-loss records (U.S. House, 1952, 1508).

The changes that the 1950s brought to Brooklyn's population mix and the demographics of the environs of Ebbets Field, along with the dispersal of a portion of the team's fan base to the automobile dependent suburbs, hardly provide a sufficient explanation for the lackluster level of Dodger attendance in the team's last years in Brooklyn. Demography and geography were not destiny, as the experiences of teams in other cities demonstrated. Competitive performance on the field yielded box office rewards, even for teams offering a less compelling on field attraction than that played out for Ebbets Field's diminishing paying customers. Comparably aging, transit and parking challenged, and geographically undesirable stadium sites in Cincinnati, Chicago, St. Louis, and Philadelphia bucked the trends held responsible for the Dodgers' plight as the 1950s wore on. At a minimum, the rest of the league registered an advance over pre-World War II attendance levels that the Dodgers could not: in 1955, the world champion Dodgers shared the distinction with the hopelessly inept last place Pittsburgh Pirates of being the only teams in the National League drawing fewer fans to their home games than in 1941.

The 1950s were a difficult decade for the baseball business in the aftermath of the boom times of the first post-war years. However, the White Sox, the Reds, the Phillies and the Cardinals managed to attract greater numbers of fans even as Dodger attendance declined, although Chicago's Comiskey Park, Cincinnati's Crosley Field, Philadelphia's Shibe Park and St. Louis's Sportsman's Park were no more conveniently situated or up to date than Brooklyn's Ebbets Field. The second division Detroit Tigers in the American League matched the attendance marks being hit by the consistently outstanding Dodgers. Perhaps, especially noteworthy in light of the readiness to attribute contemporary-and to anticipate future-Ebbets Field attendance problems to the growing minority population in its environs (and considered off limits by the 
team's white and increasingly suburban traditional fan base) is the Philadelphia Phillies' ability to draw almost a million and half fans to run down, decrepit Shibe Park in 1964-far more than any Brooklyn Dodger attendance mark in the preceding decade -despite being located in the black ghetto of North Philadelphia, even as it was being engulfed in a major race riot that summer, something that never confronted Dodger fans in the 1950s (Kuklick, 1993, 155-59).

Whatever the increase in black attendance at major league games after the color line was breached, it could not arrest the sharp downward trend in major league game attendance in the years after Robinson's debut which saw total major league attendance fall from $19,874,539$ in 1947 to $17,462,977$ in 1950. This was a downward trend in which Brooklyn proved to be the pacesetter. Between 1947 and 1950, Dodger attendance dropped by $34 \%$ (from $1,807,000$ to $1,185,000$ ) while attendance in other National League cities fell by only $20 \%$ (from $8,853,000$ to $6,840,000$ ). In 1947, Brooklyn accounted for $17 \%$ of total attendance in the 8 team National League (a "premium" of 5 percentage points over its proportionate $12 \%$ share, and even that was down from the $20 \%$ in 1946-and the 25\% in 1941); in 1950 the Brooklyn percentage was down to $14 \%$ ).

Nor was Brooklyn alone in failing to register a box office boost from integration. Comparing attendance in each National League city in the last year before each team integrated and the first season following integration reveals that integration failed to increase attendance for seven out of the eight clubs in the league.

\begin{tabular}{|l|l|l|}
\hline Team & Pre-Integration Home Attendance & Post-Integration Home Attendance \\
\hline Brooklyn & $1,796,824(1946)$ & $1,398,398,967(1948)$ \\
\hline New York & $1,459,269(1948)$ & $1,008,876(1950)$ \\
\hline Boston & $1,081,795(1949)$ & $487,487,475(1951)$ \\
\hline Chicago & $1,024,826(1952)$ & $748,183(1954)$ \\
\hline Pittsburgh & $572,757(1953)$ & $469,397(1955)$ \\
\hline Cincinnati & $548,086(1953)$ & $693,662(1955)$ \\
\hline St. Louis & $880,242(1953)$ & $849,130(1955)$ \\
\hline Philadelphia & $934,798(1956)$ & $931,110(1958)$ \\
\hline
\end{tabular}

36 A further comparison reinforces the conclusion that integration did not stimulate attendance, with any increased black patronage more than counter-balanced by a massive fall off among white fans. In his recent biography of Willie Mays, James S. Hirsch writes that

by the time Mays reached the majors [in 1951], one of the central fears about integration had already been dispelled-that black players would damage the value of a baseball franchise by alienating white fans. The experience of the Brooklyn Dodgers and Cleveland Indians had proven that false [...]. But Mays's arrival also accelerated integration. His popularity proved that black players were economic assets-Mays was baseball's biggest attraction (Hirsch, 2010, 223). 


\section{attendance was declining by $20 \%$ between 1947 and 1950, attendance in the virtually} lily white American League (in which only the Cleveland Indians were integrated in 1950 in contrast to the integrated rosters of the National League's Brooklyn, New York and Boston teams in that year), declined by less than $4 \%$. Similarly, in contrast to the $34 \%$ decline in Dodger attendance (and 35\% decline in New York Giant attendance) between 1947 and 1950 the cross-town Yankees, who would not field a black ball player until 1955, dropped by only $4 \%$ (from $2,178,937$ to $2,081,380$ ), although all three teams faced the same novel threats to live attendance at their inner city ball parks, most prominently the shift in population to suburbia and the competition from television ${ }^{6}$.

Finally, the way in which the baseball map was rearranged after a half century of stability certainly did not testify to the success of racial integration as a business proposition. Beginning with the move of the Boston Braves to Milwaukee in 1953, followed by that of the St. Louis Browns to Baltimore in 1954 and the Philadelphia Athletics to Kansas City in 1955 and culminating with the departure of the Brooklyn Dodgers and New York Giants for California in 1958, in each case it was the team that had outpaced a cross town rival (the Red Sox in Boston, the Cardinals in St. Louis, the Phillies in Philadelphia and the Yankees in New York) in the hiring of black ball players that left town, abandoning traditional homes in favor of the clubs that had resisted fielding black ball players ${ }^{7}$. Racial integration thus failed this most fundamental test of a team's viability and staying power.

\section{Conclusion}

In recent years, scholars have paid increasing attention to the civil rights struggle in the north in the years after World War II (Sugrue, 2008; Bondi, 2003; Chen, 2006). An overview of the racial politics of the post-war period suggests that major league baseball faced scant pressure from its overwhelmingly white public to integrate. Popular support was limited for civil rights initiatives generally. In his landmark 1944 study, An American Dilemma: The Negro Problem and American Democracy, Gunnar Myrdal had asserted that "the American Negro problem is a problem in the heart of the American." According to the Swedish scholar, the "American Dilemma" arose out of the contradiction between the "American Creed's" ideals of "the essential dignity of the individual human being, of the fundamental equality of all men, and of certain unalienable rights to freedom, justice and a fair opportunity" and the beliefs and practices of racial discrimination and oppression (Myrdal, 1962, xxi, 4, 24).

This was, however, a "dilemma" that few white Americans acknowledged at the time. To the extent it was, northerners viewed it as a southern problem, not one that affected wherethey lived. A recent historian of civil rights politics noted that "a Gallup poll found that only 6 percent of Americans supported [President Truman's] civil rights program; even among non-southern whites, it was favored by a mere 21 percent" (Leuchtenburg, 2005, 191). Only two percent of those polled a few weeks after the 1948 elections cited civil rights or ending racial discrimination as the most important problem facing Congress or the president (Gallup Poll, 1972, 774). As late as July 1949ironically enough, on the day after Jackie Robinson affirmed the loyalty of black Americans before the House Committee on Un-American Activities-New York's 
highest court upheld the lawfulness of a housing development's refusal to rent to black prospective tenants ("Stuyvesant Town Negro Ban Upheld," 20 July 1949).

When it came to racial integration, baseball had arguably moved ahead of the curve of American public opinion-but its meaning for the larger society was not as boldly progressive, or transformative, as it is usually made out to be. The story of "Baseball's Great Experiment" reveals cautious gradualism, ingrained suspicion (among both whitesand blacks) and enduring conflict as well as the more celebratory, and more often celebrated, chronicle of Jackie Robinson's victory for racial justice and the highest values of the American Creed.

\section{BIBLIOGRAPHY}

“Best Negro Players Already Taken - Veeck," Sporting News, 30 July 1947.

BIONDI, Martha, To Stand and Fight: The Struggle for Civil Rights in Postwar New York City, Cambridge, Harvard University Press, 2003.

BURNS, James MacGregor, Roosevelt: The Soldier of Freedom 1940-1945, New York, Harcourt Brace Jovanovich, 1970.

CHEN, Anthony S., “ 'The Hitlerian Rule of Quotas': Racial Conservatism and the Politics of Fair Employment Legislation in New York State, 1941-1945," Journal of American History, 92, 2006, 1238-64.

Chicago Defender, 26 April 1947.

CONNOLLY, Harold X., A Ghetto Grows in Brooklyn, New York, New York University Press, 1977. Daily Worker, 26 April 1947.

DODSON, Dan W., "The Integration of Negroes in Baseball," The Journal of Educational Sociology, 28:2, 1954, 73-82.

DORINSON, Joseph and Joram WARMUND, "Introduction, "Jackie Robinson: Race, Sports and the American Dream, ed. Joseph Dorinson and Joram Warmund, Armonk, M. E. Sharpe, 1998.

EIG, Jonathan, Opening Day: The Story of Jackie Robinson's First Season, New York, Simon \& Schuster, 2008.

FETTER, Henry D., "Robinson in 1947: Measuring an Uncertain Impact," Jackie Robinson: Race, Sports and the American Dream, ed. Joseph Dorinson and Joram Warmund, Armonk, M. E. Sharpe, 1998, 183-92.

FREEMAN, Joshua B., Working Class New York, New York, The New Press, 2000.

FRIEDMAN, Murray, What Went Wrong: the Creation and Collapse of the Black-Jewish Alliance, New York, Simon \& Schuster, 1995.

Gallup Poll: Public Opinion 1935-1971, New York, Random House, 1972.

GLAZER Nat and Frederick HOFFMAN, "Behind the Philadelphia Strike," Politics, November 1944, 306-8. 
GOLENBOCK, Peter, Bums: An Oral History of the Brooklyn Dodgers, Chicago, Contemporary Books, 2000 (1984).

---, In the Country of Brooklyn, New York, William Morrow, 2008.

GUNTHER, John, Inside U. S. A.,New York, Harper and Brothers, 1947.

HIRSCH, James S., Willie Mays: The Life, the Legend, New York, Scribner, 2010.

JENNINGS, Jay, “A League of His Own,” New York Times Book Review, 3 June 2007.

KAHN, Roger, The Boys of Summer, New York, Harper \& Row, 1972.

KLARMAN, Michael, "Brown, Racial Change and the Civil Rights Movement," Virginia Law Review, 80:7, 1994, 7-150.

KUKLICK, Bruce, To Every Thing a Season: Shibe Park and Urban Philadelphia 1909-1976, Princeton, Princeton University Press, 1993.

LEUCHTENBURG, William E., The White House Looks South, Baton Rouge, Louisiana State University Press, 2005.

LOWENFISH, Lee, Branch Rickey: Baseball's Ferocious Gentleman, Lincoln, University of Nebraska Press, 2007.

---, “The Rise of Baseball's Racial Quota System in the 1950s," Nine, 16:2, 2008, 52-61.

MANN, Arthur, The Jackie Robinson Story, 1950, New York, Grosset \& Dunlap, 1963.

MYRDAL, Gunnar, An American Dilemma: The Negro Problem and American Democracy, New York, Harper \& Row, 1962 (1944).

New York Times. 11, 12 April, 4 July 1947.

NORWOOD, Stephen H. and Harold Brackman, “Going to Bat for Jackie Robinson," Journal of Sport History, 26:1, 1999, 118-44.

Pittsburgh Courier [PC], 19, 26 April 1947, 24, 31 May 1947, 14 June 1947.

PM, 11 April 1947.

POLENBERG, Richard, War and Society, Philadelphia, J. B. Lippincott, 1972.

PRINCE, Carl E., Brooklyn's Dodgers,New York, Oxford University Press, 1996.

RAMPERSAD, Arnold, Jackie Robinson, New York, Knopf, 1997.

ROBINSON, Jackie, edited by Charles Dexter, Baseball Has Done It, Philadelphia, Lippincott, 1964. ROEDER, Bill, Jackie Robinson, New York, Barnes, 1950.

ROWAN, Carl with Jackie Robinson, Wait Till Next Year, New York, Random House, 1960.

ROSENWAIKE, Ira, Population History of New York City, Syracuse, Syracuse University Press, 1972.

SMITH, Wendell, “The Sports Beat," Pittsburgh Courier, 26 April 1947.

"Stuyvesant Town Negro Ban Upheld by Court of Appeals," New York Times, 20 July 1949.

SUGRUE, Thomas J., Sweet Land of Liberty: The Forgotten Struggle for Civil Rights in the North, New York, Random House, 2008.

“Toiling on the Tribe Plantation," Sporting News, 13 April 1949.

TYGIEL, Jules, Baseball's Great Experiment: Jackie Robinson and His Legacy, New York, Oxford University Press, 1983. 
U.S. House of Representatives, Hearings before the Subcommittee on Monopoly Power of the Committee on the Judiciary, Part 6: Organized Baseball, 82d Cong., $1^{\text {st }}$ sess. 1951.

U.S. Senate, Hearings before the Subcommittee on Interstate and Foreign Commerce: Broadcasting and Televising Baseball Games, 83d Cong. $1^{\text {st }}$ sess. 1953.

VEECK, Bill with Ed LINN, Veeck as in Wreck, New York, Ballantine Books, 1976 (1962).

“Veeck Predicts Scramble for Colored Stars," Sporting News, 16 July 1947.

WARD, Geoffrey and Ken BURNS, Baseball: An Illustrated History, New York, Alfred A. Knopf, 1994.

WARMUND, Joram, "In the Eye of the Storm: 1947 in World Perspective," Jackie Robinson: Race, Sports and the American Dream, ed. Joseph Dorinson and Joram Warmund, Armonk, M. E. Sharpe, 1998. 3-12.

WHITE, Walter, "People, Politics and Places," Chicago Defender, 26 April 1947.

WIGGINS, David K., "Wendell Smith, the Pittsburgh Courier-Journal and the Campaign to Include Blacks in Organized Baseball 1933-1945," Journal of Sport History, 10:2, 1983, 5-29.

WILDER, Craig Steven, A Covenant with Color: Race and Social Power in Brooklyn, New York, Columbia University Press, 2000.

\section{NOTES}

1. When examined more closely, Veeck actually held out modest expectations of the pace of change in the sport's racial lineup, predicting only that within ten years Negro players will be in regular service with big league teams(New York Times, 4 July 1947).

2. Perhaps, however, this was the ever crafty Rickey's way of discouraging Dodger rivals from following his own example and maintaining Brooklyn's head start in raiding the Negro Leagues for playing talent that yielded rookie of the year award winners in 1947, 1949, 1952 and 1953 and three starting position players (Robinson and Jim Gilliam in the infield, Roy Campanella at catcher) during the 1953 season when there were only about 20 blacks in all of major league baseball.

3. In similar fashion, the same page featured pictures of Abraham Lincoln and Bill Veeck with the respective captions ". . . freed the Negroes (. . .); gives "em baseball jobs."

4. Conolly relies on and cites Karl E. Taeuber and Alma F. Taeuber, Negroes in Cities: Residential Segregation and Neighborhood Change, New York, 1969 and Annemette Sorensen, Karl E. Taeuber, and Leslie J. Hollingsworth, Jr., "Indexes of Racial residential Segregation for 109 Cities in the United States, 1940-1970", Institute for Research on Poverty (February 1970).

5. This oft-cited claim is apparently based on a single uncredited assertion of unknown reliability in the Sporting News on 23 April 1947. It is not confirmed by any other contemporary source and is not corroborated by the attendance estimates of Wendell Smith cited below.

6. The possible negative impact of integration on Brooklyn Dodger, as well as New York Giant, attendance is raised (but not answered) in Lowenfish, 2008, 52-61.

7. Seasons in which the teams that moved fielded black ball players: Brooklyn Dodgers (1947); St. Louis Browns (1947); New York Giants (1949); Boston Braves (1950); Philadelphia A's (1953). The Browns signed three black ball players in mid-July 1947. They were all released a month later and the Browns did not field another black ball player until 1951 (Tygiel, 219-222, 285). Seasons in which the teams that stayed first fielded blacks: Boston Red Sox (1959); St. Louis Cardinals (1954); Philadelphia Phillies (1957); New York Yankees (1955). 


\section{ABSTRACTS}

This paper examines three facets of the breaking of major league baseball's color line by Jackie Robinson of the Brooklyn Dodgers in 1947: the perception of blacks, the response of white players (whether teammates or opponents), and the reaction of baseball fans. By so doing, the paper will illuminate the fault-lines that characterized race relations within both the sport of baseball and the larger society as each was confronted with new challenges to long established policies and practices in the years after the Second World War.

\section{INDEX}

Keywords: attendance, color line, discrimination, integration, race relations, Robinson (Jackie)

\section{AUTHOR}

HENRY D. FETTER

Independent Scholar, Los Angeles 